\title{
Socio-Demographic Determinants of the Experience of Physical Violence among Intimate Partners in Nigeria
}

\author{
Sunday Kolawole, ALONGE \\ Nigerian Institute of Social and Economic Research \\ Ojoo, Ibadan, Nigeria; \\ Tolulope Precious, ADEKANYE \\ Graduate Intern, Nigerian Institute of Social and Economic Research \\ Ojoo, Ibadan, Nigeria.
}

\begin{abstract}
In many cultures women are viewed and treated as inferior or as second-class citizens. Gender-based violence in all its forms is an on-going problem, even in the so-called developed world. Such violence has been associated with serious health consequences, including physical, sexual, and reproductive health, psychological and behavioural problems, as well as fatal health outcomes such as homicide, suicide, and maternal mortality. This paper examined the socio-demographic factors that may predispose a Nigerian woman to experience Intimate Partner Violence (IPV). The paper made use of secondary data from (raw data) NDHS 2013. Data were collected from 21,004 respondents comprising women of childbearing age who are currently married or in union with a partner. The variables required for the analysis were taken from the raw data and analysed using both the descriptive and inferential statistics. Women in the study population reported to have experienced at least one form of physical violence by their partner, slap is the most prevalent form of IPV observed from the findings of this study, also "offence" that was perceived to be the most justified for wife beating is if a woman goes out without telling. Findings also revealed the education level affects experience of IPV, also women with primary education are likely to experience IPV more. It was recommended that there should be a reduction in spousal age difference. Also the issue of child marriage should be abolished, for her to attain some maturity and get certain level of education that will equip her for the future.
\end{abstract}

Keywords: Intimate Partner Violence, Nigerian, Socio-Demographic, Women

\section{BACKGROUND OF THE STUDY}

November 25 is the day designated by the United Nations General Assembly as the International Day for the Elimination of Violence against Women with a view to raising public awareness of violations of the rights of women. Why was this deemed necessary?

$35 \%$ of women and girls globally experience some form of physical and sexual violence in their lifetime, with up to $70 \%$ of women facing this abuse in some countries. Violence against women is a global pandemic that takes place in both public and private spaces [25].

In many cultures women are viewed and treated as inferior or as second-class citizens. Prejudices against them are deep-rooted. Gender-based violence in all its forms is an ongoing problem, even in the so-called developed world [26]. Such violence has been associated with serious health consequences, including physical, sexual, and reproductive health, psychological and behavioural problems, as well as fatal health outcomes such as homicide, suicide, and maternal mortality [17]. 
Nigeria is one of the countries with high incidence of female domestic abuse in sub-Saharan Africa, where two-thirds of women are found to be suffering male partner violence [4]. As in most African societies, the context of female domestic abuse in Nigeria is defined by women's societal relations with men. Women are traditionally obliged to surrender their entirety to their husbands, in addition to being domestically available to gratify their male partner's physical, psychological and sexual desires. Thus, women's transgressions of these expected roles lead to their beating and coercion, in an attempt to restore traditional gender order and male power.

In most Nigerian communities, domestic abuse of a female partner is acceptable and justified as made evident in Oyediran and Isiugo-Abanihe's [18] study that found that more than half of ever-married women accepted and justified wife beating and hitting as a necessary male 'duty' in other to assert manhood within the traditional family.

The 2013 National Demographic and Health Survey (NDHS) [13] shows men's attitudes toward wife beating. Twenty-five percent of men agree that wife beating is justified in at least one of the specified situations. This proportion is slightly lower than in the 2008 NDHS (30 percent). Although the decrease is not large, it may indicate that wife beating is increasingly unacceptable among men. It is however interesting to note that more women (35 percent) than men (25 percent) agree that husbands are justified in beating their wives for at least one specified reason.

Domestic violence is a widespread social problem, but due to cultural considerations especially as it manifests in a culture of silence and low reportage by media and victims, it is extremely difficult to obtain a reliable data on the incidence and prevalence of domestic violence in most neighbourhoods. Equally unreliable are the data based on official documents (police and hospital records) and this is because instances of abuse are never reported or under-reported. Issues of violence in Nigeria are believed to belong to the private realm, something that should be shielded from public consumption or outside enquiry. This culture of silence reduces the shame attached to the victim rather than condemning the perpetrators of such crimes [1].

In general, families in Nigeria have their own peculiar characteristics which make up the very foundations of the relationship between parents, one that others cannot meddle with and is considered as a private matter. Such privacy between couples is not only respected by relatives but also is observed in public places. Consequently, in case of conflicts, bystanders or onlookers may decline to interfere in what is seen as a private matter. The fact that many couples also consider their disagreements and conflicts a private matter renders them more unlikely to seek counselling and assistance, which in turn, can fuel the cycle of violence and ultimately lead not only to the development of psychological problems for the victim but also to the suffering of the family as a whole. This problem is further compounded by the fact that since men have the tendency to deny the occurrence of family abuse, the solution rests on the wife to seek help in other to prevent the breakup of the family. Such undertaking seems rather difficult given the traumatic experiences she has endured. Some agencies and self-help groups have been successful in increasing social awareness about domestic violence. However, more efforts are needed towards empowering and enabling the victims to win back the life they have lost because of domestic violence.

This paper examined the socio-demographic factors that may predispose a Nigerian woman to experience intimate partner violence. In other words, the paper examined the contribution of 
husband's characteristics, women characteristics and the joint characteristics of the husband and the wife to the experience of intimate partner violence by women.

According to the Federal Ministry of Health [9], very few studies have been carried out on intimate partner violence in Nigeria. Credence was lent to the research findings of Odujirin [15] who reported prevalence of $68.1 \%$ for domestic abuse among women in Lagos. The sexual abuse reported is consistent with previous studies in Nigeria and elsewhere $[14,10,16,2,5,8$, $7,12]$. Countless men, more especially women and girls in Nigeria are subjected to violence by some members of their families and within their communities. The lack of official statistics makes assessing the extent of the violence an almost impossible task, but survey reports [11] suggest levels of violence are shockingly high. More than a third and in some groups nearly two thirds of women and girls in Nigeria are believed to have experienced physical, sexual or psychological violence in the family $[3,24]$. Also, a past 5-year prevalence of IPV was estimated at $4 \%$ and lifetime IPV at 30\%, with $13 \%$ of women reporting lifetime emotional or financial abuse specifically; self and official reports underestimate IPV, and rates varied according to where and how women are asked (e.g., rates in health settings generally higher) $[21,20]$; about $80 \%$ of intimate partner homicides in Canada are committed by men against women; with the rate 4 times higher in women than in men $(0.44$ per 100,000 females aged 15 and over versus 0.11 for males aged 15 and over) [19].

According to Tjaden and Thoennes [22], on violence perpetrated against women, Research initially from North America and Europe, but increasingly from other regions, has demonstrated the high prevalence of violence against women globally and its adverse physical and mental health outcomes, in both the short and long term. a multi-country study on women's health and domestic violence against women gave the following global statistics which states that between $13 \%$ and $61 \%$ of women $15-49$ years old report that an intimate partner has physically abused them at least once in their lifetime. Also, between $6 \%$ and $59 \%$ of women report forced sexual intercourse, or an attempt at it, by an intimate partner in their lifetime, from $1 \%$ to $28 \%$ of women report they were physically abused during pregnancy, by an intimate partner. More than one in three women in the United States have experienced rape, physical violence, or stalking by an intimate partner in their lifetime. In the United States, women experience 4.8 million incidents of physical or sexual assault annually. However, the true prevalence of IPV is unknown because many victims are afraid to disclose their personal experiences of violence. Intimate partner violence caused 2,340 deaths in 2007; of this number, 1,640 were female and 700 were male. Studies by the 1990 s showed that both men and women could be abusers or victims of domestic violence.

It has been perceived that Intimate partner rape/violence against women has incalculable costs to present and future generations and it undermines human development [23]. It limits a woman's personal growth, her productivity, her socio-economic roles, and her physical and psychological health. Most of all it negates the right of women as humans. According to [6], violence can affect women and girls physically, psychologically, and socially, sometimes with lifelong results. Besides, women's aspirations and achievements are powerfully inhibited, not just by the injuries of physical attacks but by the implicit threat to social development [12]. Intimate partner violence is a key component of social problems. By subjecting the women to rape/violence and without a social structure that endeavours to stop this practice, the women could be made to believe that they are inferior to their counterparts and that they deserve the abuse. This can affect their self-image and perception of men in general. Bunch [6] reported that violence against women and girls is the most pervasive violation of human rights in the world. 
This paper made use of secondary data from (raw data) NDHS 2013. Data were collected from 21,004 respondents comprising women of childbearing age who are currently married or in union with a partner. The variables required for the analysis were taken from the raw data and analysed using both the descriptive and inferential statistics. In other words, percentage analysis and logistic regression models were used to carry out the data analysis.

\section{FINDINGS}

\section{Socio-Demographic characteristics of the respondents}

Table 2.1 reveals that the largest percentages of the respondents are within the age of 25 to 39 years $(22.34 \%)$ followed by those in the age group 30 to 34 years (about $18 \%$ ). The least represented group is people aged 15 to 19 years only comprising $7.81 \%$ of the total respondents while the mean age of the respondents is about 31 years. The table further shows that there is an early onset of marriage or cohabitation with a mean age of 18 years as at first cohabitation. $44.06 \%$ of the respondents entered their first union within the age 15 to 19 years, with almost a quarter of the respondents reported to have begun living with a partner within the age 10 to 14 years. Only $2.5 \%$ entered their first union after age 30 .

Monogamy is the prevalent family type as 76.2 per cent of the respondents are in monogamous relationship while only 23.8 per cent are in a polygynous relationship. Majority of the respondents are Muslims accounting for more than half of the study population (54.28\%) as against the $44.18 \%$ that are Christians, reflecting the dominance of the two religions. Only a minority of $1.54 \%$ do not belong to either religious groups. Most of the respondents also have at least one living child with only about a tenth reporting to have no living child.

With respect to their places of residence, about two thirds of the respondents (63.95\%) reside in the rural areas suggesting a relatively low level of urbanization. This probably accounts for the high proportion of women with no formal education (43.17\%), with only 8.38 per cent having tertiary education.

The data shows that sales is the most popular form of employment among the respondents as 37.77 per cent reported it as their occupation. $28.8 \%$ however are not engaged in any form of occupation. 
Table 2.1: Percentage Distribution of Respondent's by their Socio-Demographic characteristics

\begin{tabular}{|c|c|c|c|}
\hline & & Frequency & Percentage \\
\hline \multirow{7}{*}{ Age group } & $15-19$ & 1,641 & 7.81 \\
\hline & $20-24$ & 3,491 & 16.62 \\
\hline & $25-29$ & 4,693 & 22.34 \\
\hline & $30-34$ & 3,801 & 18.10 \\
\hline & $35-39$ & 3,097 & 14.74 \\
\hline & $40-44$ & 2,232 & 10.63 \\
\hline & $45-49$ & 2,049 & 9.76 \\
\hline \multirow{5}{*}{$\begin{array}{l}\text { Age at first } \\
\text { cohabitation }\end{array}$} & $10-14$ & 5,084 & 24.20 \\
\hline & $15-19$ & 9,255 & 44.06 \\
\hline & $20-24$ & 4,381 & 20.86 \\
\hline & $25-29$ & 1,759 & 8.37 \\
\hline & 30 years and above & 525 & 2.50 \\
\hline \multirow{3}{*}{ Religion } & Christianity & 9,280 & 44.18 \\
\hline & Islam & 11,400 & 54.28 \\
\hline & Others & 324 & 1.54 \\
\hline \multirow{2}{*}{ Place of Residence } & Urban & 7,572 & 36.05 \\
\hline & Rural & 13,432 & 63.95 \\
\hline \multirow{2}{*}{ Children ever born } & No living child & 2,123 & 10.11 \\
\hline & At least one living child & 18,881 & 89.89 \\
\hline \multirow{4}{*}{ Level of Education } & No Education & 9,067 & 43.17 \\
\hline & Primary education & 4,245 & 20.21 \\
\hline & Secondary & 5,932 & 28.24 \\
\hline & Higher & 1,760 & 8.38 \\
\hline \multirow{11}{*}{ Occupation } & Not working & 6,049 & 28.80 \\
\hline & Professional/technical/managerial & 1,115 & 5.31 \\
\hline & Clerical & 87 & 0.41 \\
\hline & Sales & 7,934 & 37.77 \\
\hline & Agricultural - Self employed & 179 & 0.85 \\
\hline & Agricultural - Employee & 2,367 & 11.27 \\
\hline & Household and domestic & 28 & 0.13 \\
\hline & Services & 1,017 & 4.84 \\
\hline & Skilled Manual & 2,189 & 10.42 \\
\hline & Unskilled manual & 10 & 0.05 \\
\hline & Other & 29 & 0.14 \\
\hline
\end{tabular}

Source: NDHS 2013

\section{Respondents' Partner's characteristics}

Table 2.2 discusses the characteristics of the respondent's husbands. As at the time of the survey, the mean age of the respondent's husbands was about 41 years; this is ten years above the mean age of the respondents. This indicates that husbands in the study population are ten years older than their wives on average. 
Table 2.2: Percentage Distribution of Respondents by their Partner's Socio-Demographic characteristics

\begin{tabular}{|c|c|c|c|}
\hline & & Frequency & Percentage \\
\hline \multirow{4}{*}{ Level of Education } & No Education & 7,597 & 36.17 \\
\hline & Primary education & 3,948 & 18.80 \\
\hline & Secondary & 6,363 & 30.29 \\
\hline & Higher & 3,096 & 14.74 \\
\hline \multirow{11}{*}{ Occupation } & Not working & 379 & 1.80 \\
\hline & Professional/technical/managerial & 2,733 & 13.01 \\
\hline & Clerical & 172 & 0.82 \\
\hline & Sales & 3,779 & 17.99 \\
\hline & Agricultural - Self employed & 960 & 4.57 \\
\hline & Agricultural - Employee & 6,512 & 31.00 \\
\hline & Household and domestic & 2 & 0.01 \\
\hline & Services & 1,233 & 5.87 \\
\hline & Skilled Manual & 4,294 & 20.44 \\
\hline & Unskilled manual & 935 & 4.45 \\
\hline & Other & 5 & 0.02 \\
\hline
\end{tabular}

Source: NDHS 2013

Majority of the respondents' partners are employed as only 1.8 per cent were reported as not working. Most of them however, (31\%) are employed in the agricultural sector, while about a fifth of them have manual skills. This shows that the majority still engages in agrarian economy.

Table 2.3: Differential characteristics of female respondents and their husbands

\begin{tabular}{|c|c|c|c|}
\hline \multicolumn{2}{|c|}{} & Frequency & Percentage \\
\hline \multirow{2}{*}{ Type of union } & Married & 20,263 & 96.47 \\
& Living with Partner & 741 & 3.53 \\
\hline \multirow{2}{*}{ Family type } & Monogamy & 16,005 & 76.20 \\
& Polygyny & 4,999 & 23.80 \\
\hline \multirow{3}{*}{ Cohabitation } & $0-4$ & 4,809 & 22.90 \\
Duration & $5-9$ & 4,414 & 21.02 \\
& $10-14$ & 4,068 & 19.37 \\
& $15-19$ & 2,961 & 14.10 \\
& $20-24$ & 2,162 & 10.29 \\
& $25-29$ & 1,479 & 7.04 \\
& $30+$ & 1,111 & 5.29 \\
\hline \multirow{2}{*}{ Disparity in education } & Both not educated & 6,711 & 31.95 \\
& Husband only educated & 2,356 & 11.22 \\
& Wife only educated & 886 & 4.22 \\
& Both educated & 11,051 & 52.61 \\
\hline \multirow{2}{*}{ Age difference } & Wife Older & 230 & 1.10 \\
& Age mates & 280 & 1.33 \\
& $1-5$ years & 5,776 & 27.50 \\
& 6-10 years & 7,377 & 35.12 \\
& >10 years & & 34.95 \\
\hline
\end{tabular}

Source: NDHS 2013

\section{Differential characteristics of female respondents and their husbands}

Table 2.3 shows the differential characteristics between the respondents and their husbands. The results show that only a few of the respondents $(1.10 \%)$ are older than their husbands. In the same vein, only a small proportion of the respondents $(1.33 \%)$ are of the same age with their husbands. This shows what is prevalent across the study population is for husbands to be older than their wives. The results further show that most husbands of the respondents are older than their wives by one to ten years. A total of 27.5 per cent of the respondents have 
husbands older than them by less than 6 years. On the other hand, 35.12 per cent of the respondents have older husbands of between six to ten years, while about 35 per cent have husbands older than them by more than ten years.

With regards to their respective levels of educational attainment, the majority of the respondents and their husbands (52.61\%) have at least a form of education, while only a minority of 4.22 per cent are educated while having husbands with no formal education.

Table 2.4: Percentage Distribution of Respondents by Prevalence of the experience of IPV

\begin{tabular}{|l|c|c|}
\hline \multicolumn{1}{|l|}{$\begin{array}{c}\text { Fver experienced any form of physical violence by partner } \\
\text { Yes }\end{array}$} & 2,988 & 14.23 \\
\hline $\begin{array}{l}\text { Ever been pushed, shook or had something throw at by partner } \\
\text { Yes }\end{array}$ & 1,307 & 6.22 \\
\hline $\begin{array}{l}\text { Ever been slapped by partner } \\
\text { Yes }\end{array}$ & 2,626 & 12.50 \\
\hline $\begin{array}{l}\text { Ever been punched or hit by something harmful by partner } \\
\text { Yes }\end{array}$ & 656 & 3.12 \\
\hline $\begin{array}{l}\text { Ever been kicked or dragged by partner } \\
\text { Yes }\end{array}$ & 1,060 & 5.05 \\
\hline $\begin{array}{l}\text { Ever been strangled or burnt by partner } \\
\text { Yes }\end{array}$ & 128 & 0.61 \\
\hline $\begin{array}{l}\text { Ever been threatened with knife/gun or other weapons by partner } \\
\text { Yes }\end{array}$ & 138 & 0.66 \\
\hline $\begin{array}{l}\text { Ever had arm twisted or hair pulled by partner } \\
\text { Yes }\end{array}$ & 536 & 2.55 \\
\hline
\end{tabular}

\section{Source: NDHS 2013}

\section{Prevalence and resultant effects of the experience of IPV}

Table 2.4 examines the prevalence level of the experience of Intimate Partner Violence. 14.23 per cent of the women in the study population reported to have experienced at least one form of physical violence by their partner.

The indicators used were if the respondent has ever been pushed, shook, or had something thrown at; slapped; punched or hit by something harmful; kicked or dragged; strangled or burnt; threatened with knife or gun or other weapon; or ever had her arm twisted or hair pulled by her partner. Physical violence in the form of strangulation or being burnt by partner and threats by guns, knives or other weapons are shown to be the least prevalent with only 0.61 per cent and 0.66 per cent of respondents reporting to have ever experienced such from their partners.

Slaps from partners however is seen to be the most prevalent form of physical violence observed as 12 per cent of the total respondents claimed to have been slapped by their partner before and a staggering 87.88 per cent of those who have ever experienced any form of physical abuse by their partner reporting to have been slapped at least on one occasion by their partner. 
Table 2.5: Percentage Distribution of the Respondents who have experienced IPV

\begin{tabular}{|l|c|c|}
\hline $\begin{array}{l}\text { Ever had any injury because of partner's actions - } \\
\text { Yes }\end{array}$ & Frequency & Percentage \\
\hline $\begin{array}{l}\text { Ever had bruises because of partner's actions1 - } \\
\text { Yes }\end{array}$ & 746 & 4.03 \\
\hline $\begin{array}{l}\text { Ever had eye injuries, sprains, dislocations or burns because } \\
\text { of partner2 } \\
\text { Yes }\end{array}$ & 321 & 37.94 \\
\hline $\begin{array}{l}\text { Ever had wounds, broken bones, broken teeth or other } \\
\text { serious injury because of partner3 } \\
\text { Yes }\end{array}$ & 153 & 18.09 \\
\hline
\end{tabular}

Source: NDHS 2013

Table 2.5 however goes on to describe the effects of these forms of abuse on the victims. 4.03\% of the respondents reported that the abuse by their partners has resulted in injury, with bruises ( 88.18 per cent) being the major type of injury suffered by those who have ever been injured by their partner. 18.09 per cent of those who have ever been injured by their partner reported to have had serious injuries in the form of wounds, broken bones, and broken teeth.

Table 2.6: Perception of women to IPV

\begin{tabular}{|l|c|c|}
\hline \multicolumn{1}{|l|}{$\begin{array}{c}\text { Beating justified for any of the listed reasons } \\
\text { Yes }\end{array}$} & 8,062 & 38.38 \\
\hline $\begin{array}{l}\text { Beating justified if wife goes out without telling } \\
\text { husband } \\
\text { Yes }\end{array}$ & 6,005 & 28.59 \\
\hline $\begin{array}{l}\text { Beating justified if wife neglects the children } \\
\text { Yes }\end{array}$ & 5,703 & 27.15 \\
\hline $\begin{array}{l}\text { Beating justified if wife argues with husband } \\
\text { Yes }\end{array}$ & 4,838 & 23.03 \\
\hline $\begin{array}{l}\text { Beating justified if wife refuses to have sex with } \\
\text { husband } \\
\text { Yes }\end{array}$ & 4,584 & 21.82 \\
\hline $\begin{array}{l}\text { Beating justified if wife burns the food } \\
\text { Yes }\end{array}$ & 3,271 & 15.57 \\
\hline
\end{tabular}

Source: NDHS 2013

\section{Perception of women to the experience of intimate partner violence}

Table 2.6 describes the perception of the justification of wife beating among women. 38.38\% of the respondents agreed that wife beating is justified for certain reasons. The reasons listed were if the wife goes out without telling her husband; neglects the children, argues with husband; refuses to have sex with husband; or burns the food.

Wife beating was said to be justifiable by 27.15 percent of the respondents if a woman neglects the children.23.03\% of the respondents also agreed that a man is justified in beating his wife if the wife argues with him. The "offence" that was perceived to be the most justified for wife beating is if a woman goes out without telling her husband as about 30 per cent of the women agreed with it.

\footnotetext{
${ }^{1}$ As percentage of those that have ever been injured by partner

${ }^{2}$ As percentage of those that have ever been injured by partner

${ }^{3}$ As percentage of those that have ever been injured by partner
} 
Table 2.7: Percentage distribution of Respondents by their socio-demographic characteristics and experience of Intimate Partner Violence

\begin{tabular}{|c|c|c|c|}
\hline Characteristics & $\begin{array}{l}\text { Never experienced } \\
\text { physical violence }\end{array}$ & $\begin{array}{l}\text { Ever experienced } \\
\text { physical violence }\end{array}$ & Total \\
\hline $\begin{array}{c}\text { Age in 5-year groups } \\
15-19 \\
20-24 \\
25-29 \\
30-34 \\
35-39 \\
40-44 \\
45-49\end{array}$ & $\begin{array}{l}92.20 \\
87.65 \\
85.36 \\
83.14 \\
84.18 \\
84.86 \\
86.68\end{array}$ & $\begin{array}{c}7.80 \\
12.35 \\
14.64 \\
16.86 \\
15.82 \\
15.14 \\
13.32\end{array}$ & $\begin{array}{l}1,641 \\
3,491 \\
4,693 \\
3,801 \\
3,097 \\
2,232 \\
2,049\end{array}$ \\
\hline \multicolumn{4}{|c|}{$x_{2}=97.35^{* *}$} \\
\hline 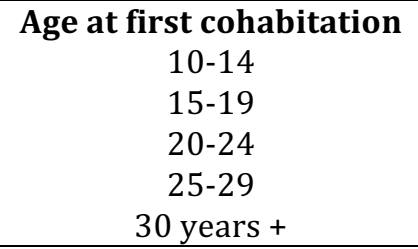 & $\begin{array}{l}89.42 \\
84.97 \\
82.47 \\
86.13 \\
91.05\end{array}$ & $\begin{array}{c}10.58 \\
15.03 \\
17.53 \\
13.87 \\
8.95 \\
\end{array}$ & $\begin{array}{c}5,084 \\
9,225 \\
4,381 \\
1,759 \\
525\end{array}$ \\
\hline \multicolumn{4}{|c|}{$x_{2}=111.57^{* *}$} \\
\hline $\begin{array}{l}\text { Religion } \\
\text { Christian } \\
\text { Islam } \\
\text { Others }\end{array}$ & $\begin{array}{l}77.11 \\
93.06 \\
77.47\end{array}$ & $\begin{array}{c}22.89 \\
6.94 \\
22.53\end{array}$ & $\begin{array}{c}9,280 \\
11,400 \\
324\end{array}$ \\
\hline \multicolumn{4}{|c|}{$x_{2}=1.1 \mathrm{e}+03^{* *}$} \\
\hline $\begin{array}{c}\text { Place of residence } \\
\text { Urban } \\
\text { Rural }\end{array}$ & $\begin{array}{l}84.60 \\
86.44\end{array}$ & $\begin{array}{l}15.40 \\
13.56\end{array}$ & $\begin{array}{c}7,572 \\
13,432\end{array}$ \\
\hline \multicolumn{4}{|c|}{$x_{2}=13.35^{* *}$} \\
\hline $\begin{array}{c}\text { Children Ever Born } \\
\text { No living child } \\
\text { At least one living child }\end{array}$ & $\begin{array}{l}92.09 \\
85.06\end{array}$ & $\begin{array}{c}7.91 \\
14.94\end{array}$ & $\begin{array}{c}2,123 \\
18,881\end{array}$ \\
\hline \multicolumn{4}{|c|}{$\chi_{2=77.13^{* *}}$} \\
\hline $\begin{array}{c}\text { Level of education } \\
\text { No education } \\
\text { Primary } \\
\text { Secondary } \\
\text { Higher }\end{array}$ & $\begin{array}{l}92.07 \\
77.39 \\
80.70 \\
90.68\end{array}$ & $\begin{array}{c}7.93 \\
22.61 \\
19.30 \\
9.32\end{array}$ & $\begin{array}{l}9,067 \\
4,245 \\
5,932 \\
1,760\end{array}$ \\
\hline \multicolumn{4}{|c|}{$x_{2}=699.39^{* *}$} \\
\hline $\begin{array}{c}\text { Respondent's occupation } \\
\text { Not working } \\
\text { Professional/technical } \\
\text { Clerical } \\
\text { Sales } \\
\text { Agricultural-Self employed } \\
\text { Agricultural-Employee } \\
\text { Household and domestic } \\
\text { Services } \\
\text { Skilled manual } \\
\text { Unskilled manual } \\
\text { Other }\end{array}$ & $\begin{array}{l}90.28 \\
88.88 \\
88.51 \\
86.03 \\
81.56 \\
71.19 \\
85.71 \\
81.71 \\
88.58 \\
90.00 \\
93.10\end{array}$ & $\begin{array}{c}9.72 \\
11.12 \\
11.49 \\
13.97 \\
18.44 \\
28.81 \\
14.29 \\
18.29 \\
11.42 \\
10.00 \\
6.90\end{array}$ & $\begin{array}{c}6,049 \\
1,115 \\
87 \\
7,394 \\
179 \\
2,367 \\
28 \\
1,017 \\
2,189 \\
10 \\
29\end{array}$ \\
\hline
\end{tabular}

\section{Source: NDHS 2013}

Table 2.7 shows the percentage distribution of the women by selected socio demographic characteristics with respect to the experience of intimate partner violence. The table shows that more respondents have never experienced physical abuse by their partners across all the selected characteristics as compared to those who have experienced any form of physical assault by their partner. 
The chi square value for current age of the respondent is statistically significant suggesting that it is related to the experience of IPV. The lowest incidence rate of IPV is seen in the age group 15-19 years which increases till age group 30-34 years before decreasing again. Women's age as at first cohabitation was also considered to see if the age at which a woman begins to live with a man has any relationship with her experience of physical abuse by her partner. The chisquare value is also significant showing that there is a significant relationship between the two variables. The same goes for religious affiliation, where the percentage distribution suggests that women who practice Islam have the least incidence of experience of IPV as only 6.94 per cent of the respondents reported ever experiencing any form of abuse by their husband.

With respect to the type of place of residence, the chi-square value shows that there is a significant relationship between the two variables. The chi-square value of the number of living children also reveals a significant relationship between this variable and experience of IPV. It is also interesting to note that women with no living children have the least incidence of physical abuse by their partners, while women who have at least one living child have a higher reported incidence of experience of physical assault.

The level of education of a woman was also assessed to see if it has any relationship with a woman's experience of IPV and the chi-square result showed that it does. Highest experience of IPV was reported by women with primary education followed by those with secondary while those with no formal education and those with post-secondary education reported a relatively low incidence rate. Women's occupation was also seen to have a statistically significant relationship with experience of IPV. 
Table 2.8: Logistic model of Likelihood of IPV experience by women's socio-demographic characteristics

\begin{tabular}{|c|c|c|c|}
\hline Characteristics & Odds Ratio & S.E & P value \\
\hline $\begin{array}{c}\text { Age group } \\
15-19(\mathrm{r}) \\
20-24 \\
25-29 \\
30-34 \\
35-39 \\
40-44 \\
45-49\end{array}$ & $\begin{array}{l}- \\
1.0915 \\
1.2030 \\
1.3606 \\
1.2089 \\
1.1325 \\
1.0307\end{array}$ & $\begin{array}{c}- \\
.1231 \\
.1343 \\
.1556 \\
.1426 \\
.1391 \\
.1298\end{array}$ & $\begin{array}{l}- \\
0.437 \\
0.098 \\
0.007 \\
0.108 \\
0.311 \\
0.810\end{array}$ \\
\hline $\begin{array}{c}\text { Age at first cohabitation } \\
10-14(\mathrm{r}) \\
15-19 \\
20-24 \\
25-29 \\
30 \text { and above } \\
\end{array}$ & $\begin{array}{c}- \\
1.0679 \\
0.9370 \\
0.7344 \\
0.4587\end{array}$ & $\begin{array}{c}- \\
.0620 \\
.0646 \\
.0688 \\
.0772\end{array}$ & $\begin{array}{l}- \\
0.258 \\
0.345 \\
0.001 \\
0.000\end{array}$ \\
\hline $\begin{array}{l}\text { Religion } \\
\text { Others (r) } \\
\text { Islam } \\
\text { Christianity }\end{array}$ & $\begin{array}{c}- \\
0.3124 \\
1.0060\end{array}$ & $\begin{array}{c}- \\
.04425 \\
.1408\end{array}$ & $\begin{array}{c}- \\
0.000 \\
0.966\end{array}$ \\
\hline $\begin{array}{c}\text { Place of Residence } \\
\text { Rural (r) } \\
\text { Urban }\end{array}$ & $\begin{array}{c}- \\
1.0506\end{array}$ & $\begin{array}{c}- \\
.0491 \\
\end{array}$ & $\begin{array}{c}- \\
0.292 \\
\end{array}$ \\
\hline $\begin{array}{c}\text { Children Ever Born } \\
\text { No living child (r) } \\
\text { At least one living child }\end{array}$ & $\begin{array}{c}- \\
1.5214 \\
\end{array}$ & $\begin{array}{c}- \\
.1397 \\
\end{array}$ & $\begin{array}{c}- \\
0.000\end{array}$ \\
\hline $\begin{array}{c}\text { Level of education } \\
\text { No Education (r) } \\
\text { Primary } \\
\text { Secondary } \\
\text { Higher }\end{array}$ & $\begin{array}{c}- \\
1.7020 \\
1.3951 \\
0.6781\end{array}$ & $\begin{array}{c}- \\
.1068 \\
.0936 \\
.0799\end{array}$ & $\begin{array}{c}- \\
0.000 \\
0.000 \\
0.001\end{array}$ \\
\hline $\begin{array}{c}\text { Respondent's Occupation } \\
\text { Not working (r) } \\
\text { Professional/technical } \\
\text { Clerical } \\
\text { Sales } \\
\text { Agricultural-Self employed } \\
\text { Agricultural-Employee } \\
\text { Household and domestic } \\
\text { Services } \\
\text { Skilled manual } \\
\text { Unskilled manual } \\
\text { Other }\end{array}$ & $\begin{array}{c}- \\
0.9775 \\
0.9581 \\
1.0971 \\
0.9794 \\
1.7442 \\
0.9544 \\
1.1568 \\
1.0422 \\
0.5406 \\
0.9834\end{array}$ & $\begin{array}{c}- \\
.1187 \\
.3343 \\
.0641 \\
.1996 \\
.1229 \\
.5319 \\
.1120 \\
.0865 \\
.5798 \\
.7291\end{array}$ & $\begin{array}{c}- \\
0.851 \\
0.902 \\
0.112 \\
0.918 \\
0.000 \\
0.933 \\
0.133 \\
0.619 \\
0.566 \\
0.982 \\
\end{array}$ \\
\hline
\end{tabular}

Source: NDHS 2013

Log likelihood $=-7809.1305$

Number of observations $=21,004$

Prob $<0.0001$

Multivariate Analysis of the likelihood of Women's experience of Intimate Partner Violence by Women's Socio-demographic Characteristics

The aim of this study is to investigate the socio-demographic factors influencing women's experience of IPV in Nigeria.

The basic assumption underlying the specification of this logistic regression model is that the likelihood of women's experience of IPV is dependent on the respondent's socio-demographic 
characteristics. The results of the logistic regression model in Table 2.8 shows that the model chi square is statistically significant at $p<0.0001$. The results further show that women in the age group 30-34 years are about 1.4 times more likely to experience IPV than those in the age group 15-19 years, as it is the age seen to have the least odds of experiencing physical assault among women of reproductive age.

It can also be seen that those who entered into cohabitation at higher ages are less likely to experience domestic abuse than those who start cohabiting with a partner at younger ages. This can be seen as those who start living with a partner at age 30 years and above are 45.8 per cent less likely to experience IPV than their counterparts who start cohabitation at age 10-14 years. Those who started living with a man at age 25-29 years are also 73.4 per cent less likely to experience IPV than those in the reference category, while only those who start cohabiting at age 15-19 years have slightly greater odds (1.07) of experiencing physical assault by their partners than those aged 10-14 years.

Using religious affiliation as an indicator, it is shown that those who practice Islam are 31.2 per cent less likely to experience IPV than those who practice Traditional/Other religions, while women practising Christianity are just as likely to experience IPV as their counterparts in the reference category.

Place of residence as a factor shows that respondents have almost equal odds of experiencing IPV irrespective of where they live, as an odds ratio of 1.05 suggests only a slight increase in likelihood for those residing in the urban areas. Interestingly, women who have at least one living child are shown to be 1.5 times more likely to experience IPV than those with no living child.

Assessing the respondents' level of education, it was seen that women with primary education only are about twice as likely to experience IPV than their counterparts with no formal education, those with secondary education 1.4 times more likely, while those with higher education are about 68 per cent less likely to be victims of IPV compared to those in the reference category.

The various forms of women's occupation also showed no major differences in likelihood of experiencing IPV in comparison to those not working, except for women who are employed in the agricultural sector and women who engage in unskilled manual jobs as they are about twice as likely and 54 per cent less likely to experience IPV respectively.

\section{CONCLUSION}

This paper examined the socio-demographic factors that may predispose a Nigerian woman to experience intimate partner violence. The report from the study shows the mean age of the respondent's husbands was about 41 years; this is ten years above the mean age of the respondents. This indicates that husbands in the study population are ten years older than their wives on average. 14.23 per cent of the women in the study population reported to have experienced at least one form of physical violence by their partner. However, Slaps from partners is seen to be the most prevalent form of physical violence observed as 12 per cent of the total respondents claimed to have been slapped by their partner and a staggering 87.88 per cent of those who have ever experienced any form of physical abuse by their partner reporting to have been slapped at least on one occasion by their partner, and bruises (88.18 per cent) being the major type of injury suffered by those who have ever been injured by their partner, it was found that violence can affect women and girls physically, psychologically and socially, 
sometimes with lifelong results. Also, it was seen that the "offence" that was perceived to be the most justified for wife beating is if a woman goes out without telling her husband as about 30 per cent of the women agreed with it.

From the women characteristics, those who practice Islam have the least incidence of experience of IPV also interesting to note that women with no living children have the least incidence of physical abuse by their partners, while women who have at least one living child have a higher reported incidence of experience of physical assault.

For the relationship between the joint characteristics of the husband and the wife, to the experience of intimate partner violence by women, the logistic regression model shows that women in the age group 30-34 years are about 1.4 times more likely to experience IPV than other age groups, while those who enter into cohabitation at higher ages are less likely to experience domestic abuse than those who start cohabiting with a partner at younger ages. It was also seen that women with primary education are about twice as likely to experience IPV than their counterparts with no formal education, while women who are employed in the agricultural sector and women who engage in unskilled manual jobs are about twice as likely and 54 per cent less likely to experience IPV respectively.

\section{RECOMMENDATIONS}

It was recommended that there should be a reduction in spousal age difference, because the higher the age difference, the higher the propensity of IPV, also the issue of child marriage should be abolished and both the male and the female child should be given equal educational opportunities for self-actualization as this will make the girl - child attain to maturity and also attain some level of education that will make her able to stand by herself and not relying solely on any man.

Members of the Public should be informed through mass media and other means of awareness creation to the fact that IPV is a public health problem, and of the urgent need to start addressing the societal norms that drive it, such as our male-controlled systems of socialization and cultural practices (patriarchal) which favour the interests of men above those of women. Non-Governmental Organizations (NGOs) should champion this public based campaign to eradicate/eliminate gender-based violence against women in our society

\section{References}

Adekeye, O. A. (2008). Prevalence and Patterns of Gender Violence: Major Variables in the Exposure to HIV/AIDS among Women in Nigeria. Gender and Behaviour, 6 (2): 1827-1840

Adidu, V. (2001). Violence against women and girls: A situational analysis. A Seminar Paper, Ahmadu Bello University, Zaria

Amnesty International (2005). Unheard Voices. Retrieved May 21, 2007 at http://web.amnesty.org/library/index/engafr440042005.

Amnesty International (2012). The state of the world's human rights. Geneva: Switzerland. http://www.amnestyusa.org/sites/default/files/air12-report-english.pdf

Bhowon, U. and Munbauhal, H. (2005). Violence against women: Experiences of women in Mauritius. Gender and Behaviour, 3: 383-395.

Bunch, C. (1997). The intolerable status quo: Violence against women and girls. Prog. Nations 1: 41-45.

Donald, F.M. and Mahlatji, L. (2006). Domestic workers' experiences of power and Oppression in South Africa. J. Psychol. Afr. 16(2): 205-214.

Fatusi, A.O. and Alatise, O.I. (2006). Intimate partner violence in Ile-Ife, Nigeria: Women's experiences and men's perspectives. Gender Behav. 4(2)764-781.

Federal Ministry of Health (2001). Review of reproductive health studies. Abuja: Federal Ministry of Health, Copyright (C) Society for Science and Education, United Kingdom 
Nigeria.

Gottman, J. and Jacobson, N. (1998). Breaking the cycle. New insights into violent relationships. London: Bloombury pp. 71-78.

Krug, E.G., Dahlberg, L.L., Mercy, J.A., Zwi, A.B. and Lozano, R. (2002). World report on violence and health. Geneva, World Health organization

Naaeke, A.Y. (2006). Breaking the silence about domestic violence: Communication for development in North Western Ghana. Gender Behav. 4(2): 782-796.

Nigeria Demographic and Health Survey (NDHS), (2013). T3 Framework Available online: www.population.gov.ng /.../2013-nigeria-demographic-and-health-survey. Accessed on October 20, 2017.

Odimegwu, C.O. (1997). The girl-child situation in South-Eastern Nigeria. Final report submitted to the InterAfrican Committee on harmful traditional practices affecting women and children, Lagos, Nigeria.

Odujurin, 0. (1999). Wife Battering in Nigeria. International Journal of Gynaecology and Obstetrics, 41, 159-164. http://dx.doi.org/10.1016/0020-7292(93)90699-W

Okembgo, C. (2000). The socio-demographic factors influencing violence against Women in selected areas of Imo State. A thesis submitted to Obafemi Awolowo University, Ile-Ife, Nigeria.

Owoaje, E.T. and Olaolorun, F.M. (2012). Women at Risk of Physical Intimate Partner Violence: A Cross-sectional Analysis of a Low-income Community in Southwest Nigeria. African Journal of Reproductive Health March 2012; 16(1): 51.

Oyeridan, K.A. and Isiugo-Abanihe, U.C. (2005). Perceptions of Nigerian women on domestic violence: Evidence from 2003 Nigeria Demographic and Health Survey. African Journal of Reproductive Health, 9(2): 38-53.

Perreault, S. (2015). Criminal victimization in Canada, 2014. Canadian Centre for Justice Statistics. Statistics Canada. Catalogue no. 85-002-X. Online

Rodgers, K. (1994). Wife assault: The findings of a national survey. Juristat. Cat. 85-002, 14(9). Canadian Centre for Justice Statistics. Statistics Canada. Ottawa, Ontario.

Statistics Canada (2016). Family violence in Canada: A statistical profile, 2014. Juristat 36(1). Catalogue no. 85002-X. Online.

Tjaden, P. and Thoennes, N. (2000). Extent, nature and consequences of intimate partner violence in the United States. http://www.ncjrs.gov/pdffiles1/nij/181867.pdf

UNAIDS, UNICEF, USAID (2002). Children on the brink. A joint report on Orphan estimates and programme strategies.

United Nations (1992). Economic and social council. Report of the working group on violence against women. Vienna: United Nations. E/CN.6/WG.2/1992/L.3.

United Women (2015). Infographics: Violence against Women. Retrieved from http://www.unwomen.org/en/digital-library/multimedia/2015/11/infographic-violence-against-women

World Bank Group (2017). Violence against Women and Girls. Database 